\title{
Burnout syndrome and associated factors among health professionals of a public hospital
}

\author{
Síndrome de burnout e fatores associados em profissionais da saúde \\ de um hospital público
}

Márcia Ebling, ${ }^{1}$ Mary Sandra Carlotto ${ }^{2}$

\begin{abstract}
Objectives:To identify the prevalence of burnout syndrome (BS) dimensions and their relationship with sociodemographic data, working variables, psychosocial variables, job satisfaction, hardiness, self-efficacy, and common mental disorders among health professionals of a public hospital.

Method: This cross-sectional study assessed 234 health professionals working at a public hospital in southern Brazil. Participants answered the Maslach Burnout Inventory, the Job Satisfaction Questionnaire, the Hardiness Scale, The General Self-Efficacy Scale, the Self-Reporting Questionnaire, and a questionnaire specifically designed for the present study to assess sociodemographic and variables related to work. Data were analyzed using descriptive and inferential statistics.

Results: An association was identified between the three dimensions of BS and sociodemographic data, variables related to work, psychosocial variables, hardy personality traits, and common mental disorders.

Conclusion: The study allowed to define a risk profile for BS, namely male, young, undergraduate workers, with a low income, who see a large number of patients per day, physicians, government employees, absence of commitment, control and challenge (hardy personality traits), low self-efficacy, job dissatisfaction, presence of common mental disorders, and intention to change career, institution, or position at current institution.
\end{abstract}

Keywords: Psychological stress, health personnel, occupational health.

\section{Resumo}

Objetivos: Verificar a prevalência das dimensões da síndrome de burnout e sua relação com variáveis sociodemográficas, laborais, psicossociais, de satisfação com o trabalho, de resistência ao estresse, de autoeficácia e também com transtornos mentais comuns em profissionais de saúde de um hospital público.

Método: Este estudo transversal avaliou 234 profissionais da saúde de um hospital público na Região Sul do Brasil. Os participantes responderam ao Maslach Burnout Inventory, ao Questionário de Satisfação no Trabalho, à Escala de Personalidade Resistente ao Estresse, à Escala de Autoeficácia Geral Percebida, ao Self-Reporting Questionnaire e a um questionário desenvolvido especificamente para este estudo para coletar dados sociodemográficos e laborais. Os dados foram submetidos a análise descritiva e inferencial.

Resultados: Foi identificada uma associação entre as três dimensões da síndrome de burnout e variáveis sociodemográficas, laborais, psicossociais, traços de personalidade resistente ao estresse e transtornos mentais comuns.

Conclusões: $O$ estudo permitiu estabelecer um perfil de risco para síndrome de burnout, a saber, trabalhadores do sexo masculino, jovens, em processo de formação (graduação), com menor remuneração, que atendem um maior número de pacientes por dia, médicos, profissionais concursados, ausência de comprometimento, controle e desafio (traços de personalidade resistente ao estresse), menor autoeficácia, insatisfação com o trabalho, presença de transtornos mentais comuns e desejo de abandonar a profissão, a instituição ou seu cargo na instituição atual.

Descritores: Estresse psicológico, profissionais da saúde, saúde ocupacional

\footnotetext{
1 Mestre em Saúde Coletiva, Universidade Luterana do Brasil (ULBRA), Canoas, RS, Brazil. ${ }^{2}$ Doutora em Psicologia Social, Universidade de Santiago de Compostela (USC), Santiago de Compostela, Spain. Professora, Programa de Pós-Graduação em Psicologia, Pontifícia Universidade Católica do Rio Grande do Sul (PUCRS), Porto Alegre, RS, Brazil.

This article originated from the Master's thesis of the same title, presented at Universidade Luterana do Brasil (ULBRA), Canoas, RS, Brazil, in 2011. Submitted June 19 2011, accepted for publication Sep 26 2011. No conflicts of interest declared concerning the publication of this article.

Suggested citation: Ebling M, Carlotto MS. Burnout syndrome and associated factors among health professionals of a public hospital. Trends Psychiatry Psychother. 2012;34(2):93-100.
} 


\section{Introduction}

Working in health care has some peculiarities that place a heavy burden of physical, cognitive and emotional demands on professionals. Excessive work, high competitiveness, conflicts, having to deal with death, lack of organization at the service and conflicts with colleagues are all variables that increase the risk of burnout or burnout syndrome (BS) in this population. ${ }^{1}$

BS is an essentially social manifestation that reflects the feelings of crisis and disorientation found in modern society, imposing tension on the most critical working fields, such as health care. ${ }^{2}$ It is also considered to be caused by chronic stress, typically observed at work environments, especially when excessive pressure and conflicts are present and when there is a scarcity of emotional rewards, recognition, and success. ${ }^{3}$

When regarded as a psychosocial phenomenon, BS is described as comprising three dimensions: emotional exhaustion, characterized by lack of energy and enthusiasm and depletion of emotional resources; depersonalization, described as negative (cold, distant) attitudes toward clients, colleagues, and the service/ organization; and reduced personal accomplishment, a behavioral phenomenon manifested as a tendency of the worker to negatively evaluate themselves, showing dissatisfaction with their own performance at work. ${ }^{4}$ Conversely, when regarded as a subjective experience, BS is described as a combination negative feelings and behaviors that have noxious implications for the subject him/herself, for other workers, for institutions, and for the quality of health care provided. ${ }^{5}$

Several occupational problems have been observed among health care workers, but BS has been growing in relevance, providing grounds for concern among hospital managers, unions, and government organizations. ${ }^{6}$ Over the past 35 years, BS has attracted the attention of investigators, workers and the general population all over the world. ${ }^{7}$

In Brazil, a 2008 study describing the state of the art of scientific production on BS identified 28 articles published in Brazilian journals and conducted with Brazilian samples; however, only seven of them included health professionals. ${ }^{8}$ Although BS is acknowledged as a work-related condition by the Brazilian Ministry of Health, ${ }^{9}$ the characteristics of the syndrome and the risk factors associated with its onset are little known. ${ }^{10}$

Studies have recommended the investigation of relationships between personal characteristics, personality traits, and work characteristics, so as to determine the effects of each of these variables on the burnout experience. ${ }^{11}$ Among the different methodologies used to study BS, an interactionist approach has shown to be more adequate to understand factors related with the condition. ${ }^{12}$

The objective of the present study was to identify the prevalence of the three dimensions of BS (emotional exhaustion, depersonalization, and personal accomplishment) and their relationship with sociodemographic data, working variables, psychosocial variables, job satisfaction, hardiness, self-efficacy, and common mental disorders among health workers of a public hospital.

\section{Methods}

This was an observational, analytical, cross-sectional epidemiological study. ${ }^{13}$ Among the 256 health professions working at the public hospital of a medium-size municipality in the Brazilian southern state of Paraná, 234 agreed to participate in the study; 22 were excluded because they were on a leave (pregnancy leave, sick leave, work accident, or vacation) or because they did not adequately respond the instruments or refused to participate.

Data were collected using a questionnaire specifically designed to investigate sociodemographic data (sex, age, marital status, education level, children), working variables (professional activity, time working in the profession, time working at the institution, weekly working hours, other jobs, income, number of patients seen daily, and employment status), and psychosocial variables (intention to change career, institution, or position at the current institution). Additionally, the following self-report instruments were applied:

1. Maslach Burnout Inventory - Human Services Survey (MBI-HSS). ${ }^{14}$ This instrument has been translated and validated into Brazilian Portuguese by Lautert. ${ }^{15}$ The MBI-HSS assesses the three dimensions of SB: emotional exhaustion (nine statements); professional accomplishment (eight statements), and depersonalization (five statements). The instrument includes 22 statements at total, which have to be rated according to their frequency using a 7-point Likert-type scale. ${ }^{16}$ In the present study, an adapted 5-point scale previously validated by Tamayo was used, as follows: $1=$ never, 2 = rarely, $3=$ sometimes, $4=$ frequently, and $5=$ always. ${ }^{17}$ MBI-HSS has shown adequate internal consistency in the three dimensions, with a Cronbach's alpha ranging from 0.84 for emotional exhaustion, through 0.73 for depersonalization, to 0.76 for reduced professional accomplishment.

2. Job Satisfaction Scale $(\mathbf{S 2 0 / 2 3 )})$. This instrument was originally developed in Spanish by Meliá \& Peiró18 and has been adapted for use in Brazil by Carlotto \& Câmara. ${ }^{19}$ It includes 20 statements 
distributed over three domains: hierarchical relation satisfaction (11 statements; Cronbach's alpha = 0.92), work environment satisfaction (five statements; alpha = 0.86 ); work intrinsic satisfaction and professional growth opportunities (four statements; alpha $=0.77$ ). A 5-point Likert-type scale is used to rate each domain: $1=$ totally dissatisfied, 2 = partially dissatisfied, 3 = indifferent, 4 = partially satisfied, and $5=$ totally satisfied.

3. Hardiness Scale. ${ }^{20}$ This instrument has been adapted to Brazilian Portuguese by Mallar \& Capitão. ${ }^{21}$ It comprises 50 statements that have to be rated from 0 to 3 , as follows: 0 = completely false, $1=$ somewhat true, 2 = mostly true, and 3 = completely true. The statements assess the three dimensions of the hardy personality construct: commitment (16 statements; Cronbach's alpha $=0.70)$, control (17 statements; alpha $=0.70$ ), and challenge (17 statements; alpha = $0.70)$. The Hardiness Scale has shown an overall internal consistency of $0.90 .{ }^{21}$

4. General Self-Efficacy Scale. ${ }^{22}$ This instrument was adapted to Brazilian Portuguese by Souza \& Souza. ${ }^{23}$ It comprises 10 statements that have to be rated according their frequency using a 5-point Likert-type scale, as follows: 0 = totally disagree, $1=$ disagree, 2 $=$ neither agree nor disagree, $3=$ agree, and $4=$ totally agree. Internal consistency of this scale lies at $0.81 .{ }^{23}$

5. Self-Reporting Questionnaire (SRQ-20). This scale has been designed by Harding et al. ${ }^{24}$ to assess the presence of common mental disorders and has been validated for use in Brazil by Mari \& Willians. ${ }^{25}$ It comprises 20 yes/no questions on physical and psychological symptoms for the detection of minor psychiatric disorders (anxiety, depression, psychosomatic reactions, irritability, and mental fatigue). Each affirmative answer corresponds to a score of 1 in the final score (sum of all scores). The scores obtained indicate the probability of the presence of non-psychotic disorders, and may range from 0 (no probability) to 20 (extreme probability). The instrument has shown a Cronbach's alpha of 0.86 , and a cutoff point of $7 / 8$, independently of sex. ${ }^{25}$

Data were collected from May to August 2010. Participants were contacted at their departments, randomly selected by four interviewers, covering all working shifts. The instruments filled by workers were placed in two boxes, one for questionnaires and instruments and the other for signed informed consent terms.

The study was approved by the Research Ethics Committee of Universidade Luterana do Brasil (protocol no. CEP-2010-002H). Department chiefs and participants were informed of the voluntary, anonymous, and confidential nature of the study, and were assured that the data collected would not be used for individual or institutional evaluation purposes.
Data were analyzed using the Statistical Package for the Social Sciences (SPSS) version 17.0. Exploratory data analyses were conducted to assess data distribution, identify omissions and outliers, and possible entry errors. Data were analyzed using descriptive and inferential statistics (Pearson's correlation, Student's $t$ test, and analysis of variance [ANOVA]). Significance was set at $\mathrm{p}<0.05$.

When assessing the prevalence of the three dimensions of BS, the cutoff points described by Shiron ${ }^{26}$ and subsequently used by Batista et al. ${ }^{27}$ were adopted. As a result, individuals presenting symptoms at least once a week (minimum score of $4=$ frequently) were considered to have BS (score 4 corresponds to score 6 in Tamayo's original scale ${ }^{17}$ ). According to Batista et al., ${ }^{27}$ the use of that cutoff point is a valid alternative for the identification of burnout levels in countries where specific cutoff points have not been validated.

\section{Results}

The health professionals included in the present sample had a mean age of $33.84 \pm 8.37$ years. Most were female $(70.9 \%)$, had completed high school $(44.1 \%)$, lived with a partner (72.6\%), had children (66.7\%), did not have a second job $(60.5 \%)$ and were paid up to three minimum wages (50.3\%). Most of the participants were nurse technicians (59.4\%), 28.2\% worked at infirmaries, and $49.6 \%$ were hired as employees (rather than government employees). Mean weekly working hours were $40.8 \pm 8.68$, and the professionals saw on average $16 \pm 14$ patients every day. Mean time working at the institution was $20 \pm 30.04$ months, compared to $91 \pm 77.44$ months working in the profession.

According to the cutoff points adopted in the present study, no high levels were observed for any of the three BS dimensions assessed. Conversely, when analyzing the association between BS dimensions and sociodemographic and working variables status, men presented higher means of depersonalization (Table 1). Also, participants attending college showed higher emotional exhaustion (2.48) and depersonalization (2.18) scores when compared with those who had completed high school, and physicians showed higher mean scores for depersonalization (2.17) when compared with nurses. Government employees also had higher emotional exhaustion scores (2.42) when compared with those hired as employees directly by the hospital (Table 1).

All sociodemographic and working variables investigated showed association with emotional exhaustion, except income (Table 2). The same was observed for depersonalization, except for intention to 
Table 1 - Association between burnout dimensions and sociodemographic and working variables

\begin{tabular}{|c|c|c|c|c|c|c|c|c|c|c|}
\hline \multirow[b]{2}{*}{ Frequency } & \multirow[b]{2}{*}{$\mathbf{n}$} & \multicolumn{3}{|c|}{ Emotional exhaustion } & \multicolumn{3}{|c|}{ Depersonalization } & \multicolumn{3}{|c|}{ Professional accomplishment } \\
\hline & & Mean & SD & $\mathbf{p}$ & Mean & SD & $\mathbf{p}$ & Mean & SD & $\mathbf{p}$ \\
\hline \multicolumn{11}{|l|}{ Sex } \\
\hline Male & 68 & 2.25 & 0.49 & 0.25 & 2.12 & 0.67 & $0.01 *$ & 3.88 & 0.56 & 0.71 \\
\hline Female & 166 & 2.14 & 0.72 & & 1.80 & 0.63 & & 3.85 & 0.63 & \\
\hline \multicolumn{11}{|l|}{ Marital status } \\
\hline Partner & 164 & 2.13 & 0.65 & 0.99 & 1.91 & 0.63 & 0.86 & 3.87 & 0.61 & 0.91 \\
\hline No partner & 62 & 2.29 & 0.70 & & 1.87 & 0.70 & & 3.85 & 0.61 & \\
\hline \multicolumn{11}{|l|}{ Children } \\
\hline Yes & 156 & 2.16 & 0.69 & 0.79 & 1.87 & 0.65 & 0.38 & 3.90 & 0.61 & 0.90 \\
\hline No & 78 & 2.18 & 0.61 & & 1.95 & 0.62 & & 3.76 & 0.61 & \\
\hline \multicolumn{11}{|l|}{ Second job } \\
\hline Yes & 90 & 2.21 & 0.60 & 0.52 & 2.00 & 0.69 & 0.05 & 3.79 & 0.57 & 0.16 \\
\hline No & 138 & 2.15 & 0.71 & & 1.83 & 0.63 & & 3.91 & 0.61 & \\
\hline \multicolumn{11}{|l|}{ Education } \\
\hline Complete high school & 101 & 2.10 & 0.66 & $0.02 *$ & 1.80 & 0.63 & $0.02 *$ & 3.83 & 0.70 & 0.99 \\
\hline Attending college & 35 & 2.48 & 0.76 & $0.02 *$ & 2.18 & 0.81 & $0.02 *$ & 3.80 & 0.50 & 0.99 \\
\hline Complete college & 47 & 2.06 & 0.62 & 0.98 & 1.92 & 0.61 & 0.70 & 3.84 & 0.64 & 1.00 \\
\hline Graduate studies & 46 & 2.20 & 0.60 & 0.81 & 1.89 & 0.58 & 0.84 & 3.94 & 0.46 & 0.74 \\
\hline \multicolumn{11}{|l|}{ Profession } \\
\hline Physician & 31 & 2.27 & 0.59 & 0.14 & 2.17 & 0.68 & $0.04 *$ & 3.96 & 0.39 & 0.93 \\
\hline Nurse & 47 & 1.94 & 0.51 & 0.14 & 1.77 & 0.52 & $0.04 *$ & 3.88 & 0.62 & 0.93 \\
\hline Nurse technician & 139 & 2.22 & 0.71 & 0.98 & 1.88 & 0.67 & 0.11 & 3.82 & 0.65 & 0.67 \\
\hline Other health professionals & 17 & 2.23 & 0.68 & 0.99 & 1.93 & 0.68 & 0.61 & 3.88 & 0.63 & 0.97 \\
\hline \multicolumn{11}{|l|}{ Employment status } \\
\hline Government employees & 62 & 2.42 & 0.71 & $0.00 *$ & 1.94 & 0.72 & 0.66 & 3.88 & 0.66 & 0.87 \\
\hline Hired employees & 115 & 2.03 & 0.57 & $0.00 *$ & 1.85 & 0.52 & 0.66 & 3.93 & 0.61 & 0.87 \\
\hline Contractors & 55 & 2.21 & 0.71 & 0.19 & 1.97 & 0.81 & 0.97 & 3.86 & 0.64 & 0.99 \\
\hline
\end{tabular}

$\mathrm{SD}=$ standard deviation.

* Significant difference at $5 \%$.

Table 2 - Correlations between burnout dimensions and sociodemographic and working variables

\begin{tabular}{lccc}
\hline Frequency & Emotional exhaustion & Depersonalization & Professional accomplishment \\
\hline Age & $-0.198^{+}$ & $-0.187^{+}$ & $0.142^{*}$ \\
Patients seen daily & $0.209^{+}$ & $0.176^{*}$ & -0.67 \\
Income & -0.005 & $0.149^{*}$ & 0.032 \\
Intention to change career & $0.276^{+}$ & 0.098 & $-0.138^{*}$ \\
Intention to change institution & $0.382^{+}$ & $0.132^{*}$ & -0.078 \\
Intention to change position at the institution & $0.332^{+}$ & $0.224^{+}$ & $-0.154^{*}$ \\
\hline
\end{tabular}

* Significant correlation at $5 \%$.

+ Significant correlation at $1 \%$.

Table 3 - Association between burnout dimensions and common mental disorders

\begin{tabular}{|c|c|c|c|c|c|c|c|c|c|}
\hline & \multicolumn{3}{|c|}{ Emotional exhaustion } & \multicolumn{3}{|c|}{ Depersonalization } & \multicolumn{3}{|c|}{ Professional accomplishment } \\
\hline & Mean & SD & $\mathbf{p}$ & Mean & SD & $\mathbf{p}$ & Mean & SD & $\mathbf{p}$ \\
\hline Common mental disorders absent $(n=188)$ & 2.02 & 0.57 & $0.00 *$ & 1.81 & 0.62 & $0.00 *$ & 3.93 & 0.60 & $0.00 *$ \\
\hline Common mental disorders present $(n=46)$ & 2.78 & 0.69 & & 2.24 & 0.69 & & 3.57 & 0.56 & \\
\hline
\end{tabular}

Significant difference at $5 \%$

Table 4 - Correlations between burnout dimensions and hardiness, job satisfaction, and self-efficacy

\begin{tabular}{|c|c|c|c|}
\hline Variable & motional exhaustion & Depersonalization & Professional accomplishment \\
\hline Commitment & $-0.313^{+}$ & $-0.238^{+}$ & $0.404^{+}$ \\
\hline Control & $-0.328^{+}$ & $-0.288^{+}$ & $0.384^{+}$ \\
\hline Challenge & $-0.309^{+}$ & $-0.269^{+}$ & $0.178^{+}$ \\
\hline Hierarchical relation satisfaction & $-0.433^{+}$ & $-0.269^{\dagger}$ & $0.263^{+}$ \\
\hline Work environment satisfaction & $-0.396^{+}$ & $-0.225^{+}$ & $0.227^{+}$ \\
\hline Work intrinsic satisfaction and professional growth opportunities & $-0.437^{+}$ & $-0.259^{+}$ & $0.268^{+}$ \\
\hline Self-efficacy & $-0.166 *$ & 0.047 & $0.387^{+}$ \\
\hline
\end{tabular}

* Significant correlation at $5 \%$.

+ Significant correlation at $1 \%$. 
change career. Professional accomplishment showed association with age, with intention to change career and with intention to change position at the current institution.

Older age was associated with lower emotional exhaustion and depersonalization scores and with higher professional accomplishment scores. A larger number of patients seen daily resulted in a stronger feeling of professional non-achievement. Also, professionals with a lower income showed more distant attitudes toward their clients. Intention to change career, institution, or position at the current institution were associated with increased emotional exhaustion. Distant attitudes were only affected by intention to change institution and position at the current institution. Professional accomplishment decreased as intention to change career or position at the current institution increased.

With regard to the association between burnout dimensions and common mental disorders, higher mean scores were observed in the three dimensions among health workers carrying such disorders (Table 3 ).

In the analysis of hardiness, job satisfaction, and selfefficacy scores, an association was observed between hardiness and the three burnout dimensions (Table 4). Higher job satisfaction scores were associated with lower indices of emotional exhaustion and depersonalization and a higher degree of professional accomplishment. Results have also pointed toward a relationship between self-efficacy and MBI-HSS dimensions, revealing that a stronger perception of professional competence is associated with decreased feelings of emotional exhaustion and increased feelings of professional accomplishment.

\section{Discussion}

According to the cutoff points adopted in our analysis for the three dimensions covered by the MBI-HSS, no high levels were observed in the population assessed in any dimension. This finding may be explained by the current status of the institution investigated, where some professionals had only recently been hired and others were potentially leaving in the short term. Such a scenario brings up discussions on social desirability and professionals' difficulties in perceiving and admitting the development of distant, cold, impersonal attitudes towards patients. It also calls into question the cutoff point adopted in the present study and the absence of a criterion to regulate time working in the profession during the selection of participants.

With regard to sociodemographic variables, men showed higher levels of depersonalization than women, confirming the results of previous studies, such as those by Maslach ${ }^{28}$ and Norlund et al. ${ }^{29}$ Such difference has been explained by the cultural aspects involved in socialization processes. In the health care scenario, the idea of a stronger or easier involvement of women with the care and well-being of others continues to be prevalent. ${ }^{30}$

Our age results also confirmed the findings of previous studies by Almeida et al., ${ }^{31}$ Lautert, ${ }^{15}$ and Rosa \& Carlotto. ${ }^{32}$ Young workers usually have a poor understanding of what they can and what they cannot do, which often results in professional frustration. They are attracted to the possibility of social elevation, but at the same time often have limited abilities, inadequate training, and are usually unaware of the existence and risk of BS. ${ }^{33}$ Rosa \& Carlotto ${ }^{32}$ have explained the relationship between age and depersonalization by referring to the scarcity of opportunities that workers have to manifest and understand feelings and situations experienced daily at a health care institution, which would then favor the burnout process, especially among young workers, who are starting their careers and usually want to show their full potential in order to be accepted at the institution.

Subjects attending college showed higher levels of emotional exhaustion and depersonalization. Working while attending college may contribute to emotional exhaustion, as a result of the need to deal with a double burden of demands, excessive activities, and strict shift schedules - not to mention the usual demands faced at personal and family levels. Conversely, having completed college has been observed to provoke more distant attitudes among workers, which can possibly be explained by the higher expectations commonly observed in more qualified professionals. ${ }^{34}$

Lower income resulted in higher depersonalization scores, a finding that is similar to previous results reported for hospitals in Turkey, where workers in adverse economic conditions also showed higher depersonalization scores. ${ }^{35}$

A positive association was observed between number of patients seen daily and the emotional exhaustion and depersonalization dimensions: a larger number of patients increase implies a larger number of tasks and demands. In addition, more continuous rather than more intermittent demands can make the health care professional more vulnerable to BS. ${ }^{35,36}$ Professional practice is considered to be a predominantly emotional activity, ${ }^{37}$ i.e., it depends on the worker's stability and ability to deal with emotions. In the process model proposed for BS, when such attempts fail, the worker starts to adopt distant attitudes towards their patients in an attempt to reduce the perception of emotional exhaustion resulting from interactions often characterized by negative emotions on both parts. ${ }^{33}$ 
In the analysis of professional categories, physicians showed higher depersonalization scores. Grau et al. ${ }^{38}$ and Escribà-Agüir et al. ${ }^{39}$ have reported similar findings and have suggested that the higher number of stressors referred by this category and the two most frequently reported stressors could explain such results (making mistakes with patients and aggressive behaviors shown by some patients).

With regard to employment status, government employees were found to present higher emotional exhaustion scores than those hired directly by the hospital. Pera \& Serra-Prat ${ }^{40}$ have suggested that government employees tend to be more susceptible to burnout as a result of their lower expectations regarding career advancement.

All the three dimensions of the Hardiness Scale showed association with MBI-HSS. Our findings suggest that personalities characterized by commitment (job identification), control (thinking and acting according to one's convictions, foreseeing stressful situations and avoiding/changing them) and challenge (seeing stressors as an opportunity for personal growth) are associated with higher levels of personal accomplishment and lower levels of exhaustion and distant attitudes. A hardy personality may therefore preserve health, enhance performance, and promote less stressful lifestyle changes. ${ }^{41}$

Our findings also evidenced a relationship between self-efficacy and the three dimensions of the MBI-HSS: a stronger perception of professional competence was associated with lower emotional exhaustion and higher professional accomplishment scores. Confidence in one's own abilities as tools to cope with an extensive array of demands and unexpected situations ${ }^{23}$ is an important resource that can act as a mediator between stress and burnout. ${ }^{42}$

Increased job satisfaction scores in different arenas (hierarchical relation satisfaction, work environment satisfaction, and work intrinsic satisfaction) were associated with lower emotional exhaustion and depersonalization scores and higher professional accomplishment scores. According to Gil-Monte \& Peiró, a significant, consistent relationship has been observed between BS and job satisfaction, both in the analysis of overall scores and of specific dimensions. ${ }^{43}$

When analyzing the tendency to leave the profession, it was possible to observe that a stronger desire to change institution or to change position at the current institution was associated with increased emotional exhaustion and depersonalization scores. Jourdain \& Chênevert have found similar findings and suggested that the relationship between intention to leave the profession and exhaustion lies in the excessive demands imposed by the position, whereas its relationship with depersonalization could be explained by the lack of psychological resources to deal with stressors, weakening the commitment of professionals toward their institution and profession. ${ }^{44}$ We have observed that the stronger the desire to change profession, the lower the scores obtained for professional accomplishment. In this sense, it is possible to hypothesize that professionals not working within their preferred range of activities end up showing feelings of frustration and professional nonachievement.

Health workers presenting common mental disorders also showed higher emotional exhaustion and depersonalization scores and lower professional accomplishment scores. Silva \& Menezes ${ }^{45}$ observed that the presence of common mental disorders was associated with higher emotional exhaustion scores and lower professional accomplishment scores among communitybased health agents. Another study conducted by Souza et al. ${ }^{46}$ found that common mental disorders were significantly associated with high-demand jobs, particularly with work environment characteristics such as managerial pressure, a high level of concentration required, excess of tasks, few opportunities to make decisions and to use one's own abilities. Work conditions also seem to be directly related with the presence of anxiety and depressive states. ${ }^{47}$

Some limitations of the present study deserve to be mentioned. First, its cross-sectional design does not allow to safely establish a temporal or causal relationship between exposure and outcome. As a result, the possibility of reverse causation bias in our analysis should be taken into consideration, especially with regard to common mental disorders, job satisfaction, and intention to leave the profession, once all these variables could indeed lead to BS but also vice versa. The second limitation worth mentioning is related to the selfreport measures collected, which could originate biases resulting from work expectations and the professionals' efforts to preserve a favorable public image of themselves and of the institution, which may also have impacted the negative reactions of these professionals towards their patients. It is also necessary to take into account the status of the institution at the time of the investigation, once it was going through managerial and administrative changes, which may have had impacts on the workers' responses. Also, our findings may have been affected by the healthy worker effect, commonly observed in crosssectional occupational epidemiological studies, which often tends to exclude more severely sick workers from the samples. ${ }^{48}$ This situation may underestimate the real magnitude of the risks identified, once the workers most severely affected do not manage to keep their jobs 
or are usually absent from work for health reasons. In addition, some of the workers refused to answer the instruments, a phenomenon that has been interpreted by Heus \& Diekstra ${ }^{49}$ as a sign suggestive of BS, once such individuals see taking part in a survey as an excess task (probably as a result of exhaustion). Finally, the adoption of a cutoff point based on a theoretical burnout model that takes into consideration the frequency of symptoms, rather than normalized cutoff points, may also have partially affected our results.

\section{Conclusion}

Our findings allowed to outline a risk profile for BS, namely male, young workers, still attending college, with a low income, who see a large number of patients per day, physicians, government employees, absence of commitment, control and challenge (hardy personality traits), low self-efficacy, job dissatisfaction, presence of common mental disorders, and intention to change career, current institution, or position at the current institution.

Our study points to a complex array of variables that can either prevent or cause BS. Therefore, new studies are warranted, with different designs, including other variables and applying more specific exclusion criteria, e.g. a long time working in the profession and/or at the institution. Notwithstanding, our results underscore the importance of interventions aimed at analyzing the relationship between BS and sociodemographic variables, work status, psychosocial characteristics, and common mental disorders among different types of workers.

\section{References}

1. Rodriguez-Marín J. Psicología social de la salud. Madrid: Sínteses; 1995.

2. Cebrià-Andreu J. El síndrome de desgaste profesional como problema de salud pública. Gac Sanit. 2005;19:470.

3. Harrison BJ. Are you to burn out? Fund Raising Manage. 1999;30:25-8.

4. Maslach C, Jackson SE. The measurement of experienced burnout. J Occup Behav. 1981;2:99-113.

5. Gil-Monte PR. El síndrome de quemarse por el trabajo (burnout). Una enfermedad laboral en la sociedad del bienestar. Madrid: Pirámide; 2005.

6. Taborda L, Chinazzo I, Carlotto MS. Síndrome de burnout em profissionais da saúde de unidades básicas de saúde. Rev Inic Cient ULBRA. 2010;1:205-15.

7. Schaufeli BW, Leiter MP, Maslach C. Burnout: 35 years of research and practice. Career Dev Int. 2009;14:204-20.

8. Carlotto MS, Câmara SG. Análise da produção científica sobre a síndrome de burnout no Brasil. Psico. 2008;39:152-8.
9. Brasil, Ministério da Saúde. Doenças relacionadas ao trabalho: manual de procedimentos para os serviços de saúde. Brasília: Ministério da Saúde; OPAS/OMS; 2001.

10. Batista JBV. Síndrome de burnout em professores do ensino fundamental: um problema de saúde pública não percebido [tese]. Recife: Centro de Pesquisas Aggeu Magalhães, Fundação Oswaldo Cruz; 2010.

11. Lent J. The impact of work setting, demographic factors, and personality factors on burnout of professional counselors [dissertation]. Akron: University of Akron; 2010.

12. Burisch M. A longitudinal study of burnout: the relative importance of dispositions and experiences. Work Stress. 2002;16:1-17.

13. Grimes DA, Shulz KF. An overview of clinical research: the lay of the land. Lancet. 2002;359:57-61.

14. Maslach C, Jackson SE. MBI: Maslach Burnout Inventory, Manual Research Edition. Palo Alto: University of California/ Consulting Psychologists; 1986.

15. Lautert L. O desgaste profissional: uma revisão da literatura e implicações para a enfermeira. Rev Gaucha Enferm. 1997; 18:83-93.

16. Maslach C, Leiter MP. The truth about burnout: how organizations cause personal stress and what to do about it. San Francisco: Jossey-Bass; 1997.

17. Tamayo MR. Relação entre a síndrome do burnout e os valores organizacionais no pessoal de enfermagem de dois hospitais públicos [dissertação]. Brasília: Universidade de Brasília; 1997.

18. Meliá JL, Peiró JM. La medida de la satisfacción laboral en contextos organizacionales: el cuestionario de satisfacción S20/23. Psicologemas. 1989;3:59-74.

19. Carlotto MS, Câmara SG. Propriedades psicométricas do Questionário de Satisfação no Trabalho (S20/23). Psico-USF. 2008;13:203-10.

20. Kobasa SC, Maddi SR, Khan S. Hardiness and health. A prospective study. J Pers Soc Psychol. 1982;42:168-77.

21. Mallar SC, Capitão CG. Burnout e hardiness: um estudo de evidência de validade. Psico-USF. 2004;9:19-29.

22. Schwarzer R, Jerusalem M. Generalized Self-Efficacy Scale. In: Weinman J, Wright $S$, Johnston $M$. Measures in health psychology: a user's portfolio. Causal and control beliefs. Windsor: NFER-Nelson; 1995. p. 35-7.

23. Souza I, Souza MA. Validação da escala de auto-eficácia geral percebida. Rev Univ Rural (Cienc Hum). 2004;26:12-7.

24. Harding TW, Arango MV, Baltazar J, Climent CE, Ibrahim HHA, Ladrido-Ignacio $L$, et al. Mental disorders in primary health care: a study of their frequency and diagnosis in four developing countries. Psychol Med. 1980;10:231-42.

25. Mari JJ, Willians P. A validity study of a psychiatric screening questionnaire (SRQ-20) in primary care in the city of São Paulo. Br J Psychiatry. 1986;148:23-6.

26. Shiron A. Burnout in work organizations. In: Cooper CL, Robertson I, editors. International review of industrial and organizational psychology. New York: Wiley \& Sons; 1989. p. 25-48.

27. Batista JBV, Carlotto M, Coutinho A, Souto A, Silva LG. Prevalência da síndrome de burnout e fatores sociodemográficos e laborais em professores de escolas municipais da cidade de João Pessoa, PB. Rev Bras Epidemiol. 2010;13:502-12.

28. Maslach C. Entendendo o burnout. In: Rossi AM, Perrewé $\mathrm{PL}$, Sauter SL, organizadores. Stress e qualidade de vida no trabalho: perspectivas atuais de saúde ocupacional. São Paulo: Atlas; 2005. p. 41-55. 
29. Norlund S, Reuterwall C, Höög J, Lindahl B, Janlert U, Birgander LS. Burnout, working conditions and gender results from the northern Sweden MONICA Study. BMC Public Health. 2010;10:326.

30. Maslach C, Jackson SE. The role of sex and family variables in burnout. Sex Roles. 1985;12:83 7-51.

31. Almeida KM, Souza LAS, Carlotto MS. Síndrome de burnout em funcionários de uma fundação de proteção e assistência social. Rev Psicol Organ Trab. 2009;9:86-96.

32. Rosa C, Carlotto MS. Síndrome de burnout e satisfação no trabalho em profissionais de uma instituição hospitalar. Rev SBPH. 2005;8:1-15.

33. Cherniss C. Professional burnout in the human service organizations. New York: Praeger; 1980.

34. Schulz R, Greenley JR, Brown R. Organization, management, and client effects on staff burnout. J Health Soc Behav. 1995;36:333-45.

35. Demir A, Ulosoy M, Ulosoy MF. Investigation of factors influencing burnout levels in professional and private lives of nurses. Int J Nurs Stud. 2003;40:807-27.

36. Cordes $\mathrm{CL}$, Dougherty TW. A review and an integration of research on job burnout. Acad Manage Rev. 1993;18:621-56.

37. Rose J, Glass N. An Australian investigation of emotional work, emotional well-being and professional practice: an emancipatory inquiry. J Clin Nurs. 2010;19:1405-14.

38. Grau A, Flichtentrei $D$, Suñer R, Prats M, Braga F. Influencia de factores personales, profesionales y transnacionales en el síndrome de burnout en personal sanitario hispanoamericano y español (2007). Rev Esp Salud Publica. 2009;83:215-30.

39. Escribà-Agüir V, Artazcoz L, Pérez-Hoyos S. Efecto del ambiente psicosocial y de la satisfacción laboral en el síndrome de burnout en médicos especialistas. Gac Sanit. 2008;22:300-8.

40. Pera G, Serra-Prat M. Prevalencia del síndrome del quemado y estudio de los factores asociados en los trabajadores de un hospital comarcal. Gac Sanit. 2002;16:480-6.
41. Moreno JB, Garrosa HE, Gonzalez GJL. Personalidad resistente, burnout y salud. Escr Psicol. 2000;4:64-77.

42. Schwarzer R, Hallum S. Perceived teacher self-efficacy as a predictor of job stress and burnout: mediation analyses. Appl Psychol Int Rev. 2008;57:152-71.

43. Gil-Monte PR, Peiró JM. Desgaste psíquico en el trabajo: el síndrome de quemarse. Madrid: Síntesis; 1997.

44. Jourdain G, Chênevert $D$. Job demands - resources, burnout and intention to leave the nursing profession: a questionnaire survey. Int J Nurs Stud. 2010;47:709-22

45. Silva ATC, Menezes PR. Burnout syndrome and common mental disorders among community-based health agents. Rev Saude Publica. 2008;42:921-9.

46. Souza SF, Carvalho FM, Araujo TM, Porto LA. Fatores psicossociais do trabalho e transtornos mentais comuns em eletricitários. Rev Saude Publica. 2010;44:710-7.

47. Capitão CG, Mesquita KL. A depressão em trabalhadores de uma frente de trabalho. Rev Psicol UnC. 2005;2:93-102.

48. McMichael AJ. Standardized mortality ratios and the healthy worker effect: scratching beneath the surface. J Occup Med. 1976; 18:165-8.

49. Heus P, Diekstra RF. Do you teachers burnout more easily? A comparison of teachers with other social professions on work stress and burnout symptoms. In: Vanderbergue R, Huberman MA, editors. Understanding and preventing teacher burnout: a source book of international practice and research. Cambridge: Cambridge University Press; 1999. p. 269-84.

\section{Correspondence}

Márcia Ebling

Av. Felipe Wandscheer, 5611/25, Bairro Cognópolis

85856-530 - Foz do Iguaçu, PR - Brazil

Tel.: +55-45-3573-5979, +55-45-8405-0551

E-mail: marciaebling@gmail.com 